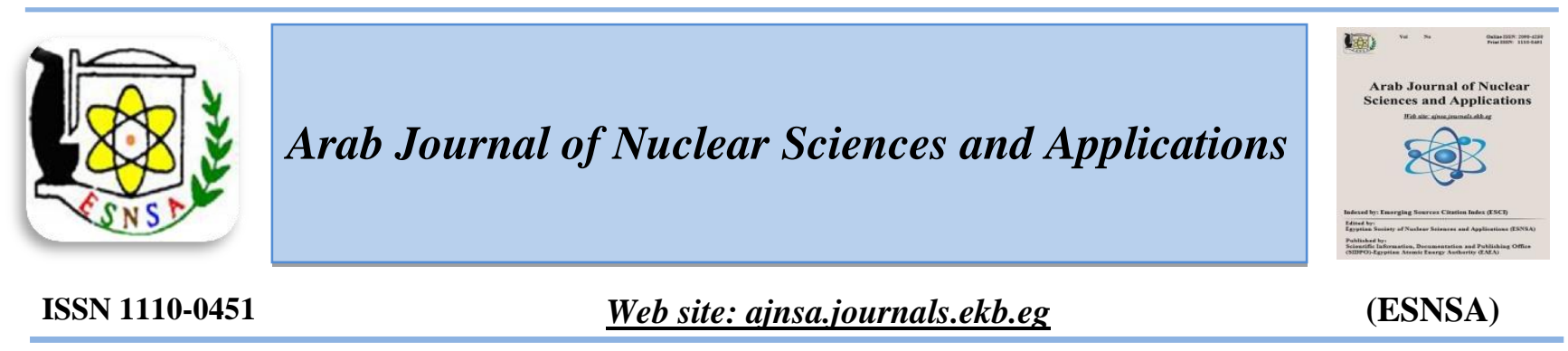

\title{
Comparative Effects of Nano-Selenium and Sodium Selenite Supplementation on Blood Biochemical Changes in Relation to Growth Performance of Growing New Zealand White Rabbits
}

\author{
S.S. Emara, H.M. El-Zaher, M.I. Michael and S.Y. Eid* \\ Biological Applications Department, Radioisotopes Applications Division, Nuclear Research Center, Atomic Energy \\ Authority, Cairo, Egyp
}

Received $3^{\text {rd }}$ Oct. 2018 The present study was conducted to compare the effect of Nano-selenium (Nano-Se) and sodium selenite Accepted $15^{\text {th }}$ May 2019 (SSe) on growth performance, antioxidative status and blood biochemical changes of growing New Zealand White (NZW) rabbits. The total number of five-week old rabbits were divided randomly into three groups (each of 24, 12 males and 12 females) were used. The first group was served as a placebo; in groups 2 and 3, each rabbit was intramuscularly injected once a week with 4ml solution of Nano-Se or $\mathrm{SSe}$, respectively. The solution was adjusted to provide $30 \mu \mathrm{g} \mathrm{Se} / \mathrm{kg} /$ live body weight. Growth trial lasted for two months. Results demonstrated that rabbits with Nano-Se treatment showed a higher rate in the total gain and daily gain weight compared to SSe and the control. Nano-Se and SSe showed lower AST and ALT activities than the control, with a high advantage for SSe. Both Nano-Se and SSe additives increased significantly GR and TAC activities compared to the control, the upper hand recorded by Nano-Se. MDA activity recorded a similar trend using Nano-Se with significant decrement than other groups. TC, LDL, VLDL, triglycerides, and phospholipids decreased significantly due to Nano-Se group than the others. Nano-se and SSe recorded a highly significant HDL, and triglycerides and VLDL than control, respectively. T3 and T4 levels were elevated dramatically in Nano-se group, also feed efficiency, feed conversion ratio and daily gain were improved. It can be concluded that Nano-se supplementation caused positive changes in blood constituents which improved growth performance of growing NZW rabbits more than SSe.

Keywords: Nano-selenium, Sodium selenite, Blood biochemical, Growth performance, Rabbits

\section{Introduction}

Rabbits meat is considered a popular Mediterranean food in European and North African countries, and it plays an important role in the national economy of these countries. It may be excellent to produce specific functional foods since its good properties such as the fatty acid profile, mineral and vitamin contents could be further enriched via feeding $[6,21]$.

Selenium (Se) is an essential element required for normal growth, reproduction, fertility, immune system, hormone metabolism and antioxidant defense systems in animals and humans' body $[3,4,25,36,37]$. Se-deficiency causes insufficient immunity, low production ability. Therefore, animal diets require supplemental Se in organic or inorganic forms to provide a margin of safety against deficiency and to maintain productive performance [10].

Subsequent studies reported that Nano-elemental Se possesses comparable efficiency with other $\mathrm{Se}$ sources [42]. Recently, Nano-elemental Se (Nano$\mathrm{Se}$ ) has attracted more attention because of its high bioavailability, high catalytic efficiency, strong adsorbing ability, and low toxicity compared with selenite in rats [17], mice [38], chickens [39], and sheep and goats $[33,34]$.

Corresponding author: sanaemara014@yahoo.com

DOI: 10.21608 /ajnsa.2019.5423.1124

(C) Scientific Information, Documentation and Publishing Office (SIDPO)-EAEA 
However, little studies on the effect of the Nano-Se in growing rabbits have been conducted, and the findings are rather inconsistent. Thus, the purpose of this experiment is to study the impact of supplementary Nano-Se on blood biochemical changes in growth performance of growing rabbits in comparison with selenium as sodium selenite.

\section{Materials And Methods}

This study was carried out in the farm belonging to the rabbit's research and breeding Project, Nuclear Research Center, Egyptian Atomic Energy Authority, Inshas, Egypt.

\section{1-Experimental design}

This experiment was carried out during the period from February to April 2016, using 72 weaned New Zealand White rabbits, aged of five weeks with nearly equal body weight $(625.3 \pm 3.7 \mathrm{~g})$. Three groups of 72 rabbits were divided randomly (12 male and 12 female each); group one was weekly injected (IM) with $4 \mathrm{ml}$ double distilled water as a placebo, while groups 2 and 3 were supplemented with intramuscular injection (I.M) once a week with $4 \mathrm{ml}$ solution of Nano-Se or SSe, respectively. The solution was adjusted to provide $30 \mu \mathrm{g} \mathrm{Se} / \mathrm{kg} / \mathrm{live}$ body weight. The experiment lasted for two months.

\section{2-Animal management}

The rabbitry building was naturally ventilated through wired windows and provided with electronic controlled sided exhaustion fans. Rabbits were individually housed in galvanized wired battery cages $(50 \times 55 \times 39 \mathrm{~cm})$; each cage had its feeder and automatic nipple drinker. Feed and water were offered ad libitum. All animals were kept under the same managerial, hygienic and environmental conditions and were maintained and treated in adherence to the accepted standards of the humane treatment of animals. The rabbits in all experimental groups were vaccinated with clostridial enterotoxaemia bloat, bacterial and viral immunization (Veterinary Research and Vaccines, Research Institute, Cairo, Egypt).

\section{3-Animal feeding}

Ingredients and chemical analyses of the basal diet are presented in Table (1) following the recommendations reported in a previous study [23]. The samples of the experimental basal diet were ground in a hammer mill provided with a 1- $\mathrm{mm}$ pore size screen and analyzed in triplicate for their content in $\mathrm{DM}$, ash, $\mathrm{CP}(\mathrm{N} \times 6.25)$, crude fiber (CF), ether extract (EE) according to a previous publication [2]. Nitrogen-free extract (NFE) was calculated by differences.

Shanghai Stone Nano-Technology Port Co. Ltd., China provided NANO-Se CAPSULE ${ }^{\circledR}$. This product is based on the liquid Nano-Se as main ingredient for health care supplement. The sizes of elemental Se particles ranged from 60 to $80 \mathrm{~nm}$, in the form of orange powder coated in capsules each one contains $0.225 \mathrm{~g}$ of powder including Nano-Se $(45 \mu \mathrm{g})$. The calculated dose of treatments, according to live body weight, was dissolved in double distilled water using magnetic stirrer overnight, then intramuscular injected.

Table (1): The ingredients and the chemical compositions of the experimental ration

\begin{tabular}{lc}
\hline Ingredients & $(\%)$ \\
\hline Clover hay & 38.00 \\
Wheat bran & 24.00 \\
Yellow corn & 15.00 \\
Soybean meal $(44 \% \mathrm{CP})$ & 16.00 \\
Molasses & 4.00 \\
$\mathrm{NaCl}$ & 1.00 \\
Sodium bicarbonate & 0.10 \\
Di Calcium phosphate & 1.60 \\
Vitamins and Minerals & 0.30 \\
premix* & \\
Total & 100
\end{tabular}

Chemical analysis

Calculated analysis on

dry matter basis**

Crude protein $(\%)$

Ether extract (\%)

2.52

Crude fiber (\%) $\quad 14.55$

Digestible energy 2500

(Kcal/Kg diet)

Calcium

1.00

Phosphorus

0.85

$\begin{array}{ll}\text { Starch } & 50.58 \\ \text { Lysine } & 0.84 \\ \text { Methionine } & 0.29\end{array}$

*Each $1 \mathrm{Kg}$ of vitamins and minerals premix contained:Vitamin A 10,000 IU, Vitamin D3,1,800 UI; Vitamin E, $15 \mathrm{mg}$; vitamin $\mathrm{K} 3,4.5 \mathrm{mg}$; Vitamin B1, $0.5 \mathrm{mg}$; Vitamin B2, $4 \mathrm{mg}$; Vitamin B12, $0.001 \mathrm{mg}$; Folic acid, $0.1 \mathrm{mg}$; Pantothenic acid, $7 \mathrm{mg}$; Nicotinic acid, $20 \mathrm{mg}$; $1,1 \mathrm{mg}$; Mn, 60 $\mathrm{mg}$; $\mathrm{Cu}, 5.5 \mathrm{mg}, \mathrm{Zn}, 75 \mathrm{mg}$; Fe, $40 \mathrm{mg}$; Co, 0.3 mg; ; Robenidine, 52.8 mg.** According to NRC (1977) 
4-Blood sampling and analysis

After eight weeks from the starting date; at 13 weeks age, blood samples were collected from marginal ear vein of the rabbits into clean tubes in each group. Blood samples were left for clotting, then centrifuged $(4000 \mathrm{rpm})$ for ten minutes and clear serum collected and stored at $-70^{\circ} \mathrm{C}$ until the biochemical and hormonal subsequent analyses.

The following parameters were determined using commercial kits manufactured by Bio-Diagnostic Company, Egypt. These parameters were glutathione reductase (GR), total antioxidant capacity (TAC), and serum malondialdehyde (MDA). In addition, total cholesterol, high-density lipoprotein cholesterol (HDL-cholesterol), triglycerides, aspartate aminotransferase (AST) and Alanine aminotransferase (ALT) were determined.

Values of very low-density lipoprotein cholesterol (VLDL-cholesterol), low-density lipoprotein cholesterol (LDL-cholesterol), and phospholipids were determined according to Ellefson and Caraway (1976) using the following equations:

VLDL-cholesterol $=$ Triglycerides $/ 5$, and Phospholipids $=68+(0.89 \times$ Total cholesterol $)$.

LDL-cholesterol $=$ Total cholesterol $-(\mathrm{HDL}+$ VLDL-cholesterol)

Radioimmunoassay (RIA) technique was applied to determine serum concentration of triiodothyronine $\left(\mathrm{T}_{3}\right)$ and thyroxine using antibody-coated tubes kit was purchased from DIA source Immunoassay S.A. Belgium. Also, counting has been conducted in the Laboratory of Biological Applications Department, Atomic Energy Authority, using Gamma Counter. The tracers were labeled with iodine-125 $\left(\mathrm{I}^{125}\right)$.

\section{5-Growth performance}

Rabbits were individually weighed every week in the early morning at a fixed time. Body weight gain was calculated by subtracting the average initial live body weight of each replicate from the average final body weight for the same replicate. Dry matter intake determined as g per day for each rabbit. Feed conversion ratio calculated as g dry matter intake/g weight gain.

\section{6-Statistical analysis}

Statistical data were analyzed using the general linear model (GLM), the procedure of [31]

The model used is: $\mathrm{Yijk}=\mu+\mathrm{Si}+\mathrm{Tj}+(\mathrm{S} * \mathrm{~T}) \mathrm{ij}+$ eijk

Where, $\mathrm{Y}=$ the dependent variable, $\mu=$ the overall mean, $\mathrm{Si}=$ the fixed effect of Sex $(1=$ male, $2=$ female), $\mathrm{Tj}=$ the fixed effect of Treatment $(1=$ nano-Se, $2=\mathrm{SSe}, \quad 3=\mathrm{Control}),(\mathrm{S} * \mathrm{~T}) \mathrm{ij}=$ the interaction between the two factor and eijk = random error, and the significant differences between means verified by Duncan Multiple test [13].

\section{Results}

Growth performance

Growth performance of growing rabbits in terms of initial body weight (IBW), final body weight (FBW), total gain (TG) and daily gain (DG)as affected by Nano-Se and SSe supplementation is illustrated in Table (2). There were significant $(\mathrm{P}<0.0001)$ differences in FBW, TG and DG due to treatments effect. Nano-Se administration increased significantly $(\mathrm{P}<0.0001)$ DG, TG and consequently FBW more than the other groups with mean values of $24.40 \mathrm{~g} /$ day, $1465 \mathrm{~g}$ and 2092 $\mathrm{g}$, respectively. However, SSe did not show significant effect on these traits as compared with the control. Concerning sex effect, males did not differ from females in the previous estimations, except in IBW males significantly $(\mathrm{P}<0.05)$ heavier than females, but this difference has faded in the final body weight at the end of the experiment. Feed conversion ratio (feed/gain) (FCR) showed significant $(\mathrm{P}<0.0001)$ differences due to Nano-Se with lowest FCR with mean value of 4.833 versus 6.639for SSe and 6.324 for control Table (2).

\section{Liver enzymes activities}

Male rabbits had AST and ALT enzymes activity higher $(\mathrm{P}<0.05)$ than those in females Table (3). Regarding treatments, Nano-Se decreased ALT activities than in the control $(21.06 \mathrm{U} / \mathrm{mL}$; $\mathrm{P}<0.001)$. SSe showed a similar trend for AST and ALT activities with mean values about 22.20 and $19.56 \mathrm{U} / \mathrm{mL}$, respectively Table (3). 
Table (2): Effect of Nano-Se and sodium selenite on growth traits of growing NWZ rabbits (means \pm SE)

\begin{tabular}{|c|c|c|c|c|c|c|c|}
\hline Items & $\begin{array}{l}\text { Initial body } \\
\text { weight (g) }\end{array}$ & $\begin{array}{l}\text { Final body } \\
\text { weight (g) }\end{array}$ & $\begin{array}{c}\text { Total } \\
\text { gain }(\mathrm{g})\end{array}$ & $\begin{array}{c}\text { Daily } \\
\text { gain } \\
\text { (g/ day) }\end{array}$ & $\begin{array}{c}\text { Daily } \\
\text { intake } \\
\text { (g/day) }\end{array}$ & $\begin{array}{c}\text { Total } \\
\text { intake } \\
(\mathrm{kg})\end{array}$ & $\begin{array}{c}\text { Feed / } \\
\text { gain } \\
(\mathrm{g} / \mathrm{g})\end{array}$ \\
\hline \multicolumn{8}{|l|}{ Sex } \\
\hline Male & $645 \pm 0.01$ & $1949 \pm 0.03$ & $\begin{array}{c}1304 \pm \\
0.02\end{array}$ & $\begin{array}{c}21.73 \pm \\
0.01\end{array}$ & $\begin{array}{c}127.63 \pm \\
0.02\end{array}$ & $\begin{array}{c}7.658 \pm \\
0.02\end{array}$ & $\begin{array}{c}5.873 \pm \\
0.02\end{array}$ \\
\hline Female & $607 \pm 0.01$ & $1927 \pm 0.03$ & $\begin{array}{c}1320 \pm \\
0.02\end{array}$ & $\begin{array}{c}22.00 \pm \\
0.01\end{array}$ & $\begin{array}{c}128.32 \pm \\
0.02\end{array}$ & $\begin{array}{c}7.699 \pm \\
0.02\end{array}$ & $\begin{array}{c}5.832 \pm \\
0.02\end{array}$ \\
\hline Significance & $* *$ & N.S & N.S & N.S & N.S & N.S & N.S \\
\hline \multicolumn{8}{|l|}{ Treatment } \\
\hline Control & $625 \pm 0.01$ & $1899^{\mathbf{B}} \pm 0.04$ & $\begin{array}{c}1274^{\mathbf{B}} \pm \\
0.05\end{array}$ & $\begin{array}{c}21.24^{\mathrm{B}} \\
0.05\end{array}$ & $\begin{array}{c}134.33^{\text {B }} \\
\pm 0.01\end{array}$ & $\begin{array}{c}8.060^{\mathbf{A}} \\
\pm 0.01\end{array}$ & $\begin{array}{c}6.324^{\mathbf{A}} \\
\pm 0.01\end{array}$ \\
\hline Nano-Se & $627 \pm 0.04$ & $2092^{\mathrm{A}} \pm 0.07$ & $\begin{array}{c}1465^{\mathrm{A}} \pm \\
0.06\end{array}$ & $\begin{array}{c}24.40^{\mathrm{A}} \pm \\
0.06\end{array}$ & $\begin{array}{c}117.92^{\mathbf{A}} \\
\pm 0.02\end{array}$ & $\begin{array}{l}7.075^{\text {B }} \\
\pm 0.02\end{array}$ & $\begin{array}{c}4.833^{\mathbf{B}} \\
\pm 0.02\end{array}$ \\
\hline $\mathrm{SSe}$ & $625 \pm 0.01$ & $1822^{\mathbf{B}} \pm 0.03$ & $\begin{array}{c}1197^{\mathbf{B}} \\
0.06\end{array}$ & $\begin{array}{c}19.95^{\mathbf{B}} \\
0.06^{-}\end{array}$ & $\begin{array}{c}131.67^{\text {B }} \\
\pm 0.02\end{array}$ & $\begin{array}{c}7.900^{\mathrm{A}} \\
\pm 0.02\end{array}$ & $\begin{array}{c}6.639^{\mathrm{A}} \\
\pm 0.02\end{array}$ \\
\hline Significance & N.S & $* * *$ & $* * *$ & $* * *$ & $* * *$ & $* * *$ & $* * *$ \\
\hline \multicolumn{8}{|c|}{$\begin{array}{l}\text { Interactions } \mathrm{S} * \mathrm{~T} \\
\text { Male }\end{array}$} \\
\hline Control & $643 \pm 0.02$ & $1894 \pm 0.03$ & $\begin{array}{c}1251 \pm \\
0.02\end{array}$ & $\begin{array}{c}20.90 \pm \\
0.01\end{array}$ & $\begin{array}{l}133.0 \pm \\
1.15\end{array}$ & $\begin{array}{c}7.978 \pm \\
0.07\end{array}$ & $6.363 \pm 0.08$ \\
\hline Nano-Se & $643 \pm 0.02$ & $2115 \pm 0.03$ & $\begin{array}{c}1472 \pm \\
0.02\end{array}$ & $\begin{array}{c}24.50 \pm \\
0.01\end{array}$ & $\begin{array}{c}118.5 \pm \\
4.01\end{array}$ & $\begin{array}{c}7.110 \pm \\
0.24\end{array}$ & $\begin{array}{c}4.837 \pm \\
0.20\end{array}$ \\
\hline $\mathrm{SSe}$ & $649 \pm 0.02$ & $1838 \pm 0.03$ & $\begin{array}{c}1189 \pm \\
0.03\end{array}$ & $\begin{array}{c}19.89 \pm \\
0.01\end{array}$ & $\begin{array}{c}131.4 \pm \\
1.09\end{array}$ & $\begin{array}{c}7.885 \pm \\
0.07\end{array}$ & $6.606 \pm 0.17$ \\
\hline Female & & & & & & & \\
\hline Control & $607 \pm 0.01$ & $1905 \pm 0.03$ & $\begin{array}{c}1298 \pm \\
0.02\end{array}$ & $21.60 \pm 0.01$ & $135.7 \pm 1.71$ & $8.143 \pm 0.10$ & $\begin{array}{c}6.282 \pm \\
0.13\end{array}$ \\
\hline Nano-Se & $612 \pm 0.01$ & $2068 \pm 0.03$ & $\begin{array}{c}1456 \pm \\
0.02\end{array}$ & $\begin{array}{c}24.30 \pm \\
0.01\end{array}$ & $\begin{array}{c}117.3 \pm \\
3.78\end{array}$ & $\begin{array}{l}7.040 \pm \\
0.23\end{array}$ & $\begin{array}{l}4.827 \pm \\
0.15\end{array}$ \\
\hline $\mathrm{SSe}$ & $601 \pm 0.01$ & $1807 \pm 0.03$ & $\begin{array}{c}1206 \pm \\
0.04\end{array}$ & $\begin{array}{c}20.10 \pm \\
0.01\end{array}$ & $\begin{array}{c}131.9 \pm \\
1.29\end{array}$ & $\begin{array}{l}7.915 \pm \\
0.08\end{array}$ & $\begin{array}{c}6.562 \pm \\
0.12\end{array}$ \\
\hline Significance & N.S & N.S & N.S & N.S & N.S & N.S & N.S \\
\hline
\end{tabular}

${ }^{I}$ In each factor means in the same column with different superscripts are significantly different

$2 *=\mathrm{P}<0.05, * *=\mathrm{P}<0.01, * * *=\mathrm{P}<0.001$

Table (3): Effect of Nano-Se and sodium selenite on liver enzymes activity of growing NZW rabbits (means \pm SE)

\begin{tabular}{ccc}
\hline Items & AST $(\mathrm{U} / \mathrm{mL})$ & ALT $(\mathrm{U} / \mathrm{mL})$ \\
\hline sex & & \\
Male & $26.85 \pm 1.16$ & $22.84 \pm 1.04$ \\
Female & $24.37 \pm 1.55$ & $21.15 \pm 0.91$ \\
Significance & $*$ & $*$ \\
\hline Treatment & $27.94^{\mathrm{A}} \pm 1.36$ & $25.37^{\mathrm{A}} \pm 1.30$ \\
Control & $26.70^{\mathrm{A}} \pm 1.41$ & $21.06^{\mathrm{B}} \pm 0.89$ \\
Nano-Se & $22.20^{\mathrm{B}} \pm 1.29$ & $19.56^{\mathrm{B}} \pm 0.73$ \\
SSe & $* * *$ & $* * *$ \\
Significance & & \\
\hline Interactions S*T & $29.55 \pm 0.58$ & $25.80 \pm 1.31$ \\
Male & $27.82 \pm 1.31$ & $22.08 \pm 0.97$ \\
Control & $23.18 \pm 1.58$ & $20.65 \pm 0.85$ \\
Nano-Se & & $24.94 \pm 1.29$ \\
SSe & $26.33 \pm 2.14$ & $20.04 \pm 0.81$ \\
Female & $25.57 \pm 1.51$ & $18.46 \pm 0.62$ \\
Control & $21.22 \pm 0.99$ & $\mathrm{~N} . \mathrm{S}$ \\
Nano-Se & $\mathrm{N} . \mathrm{S}$ & \\
SSe & &
\end{tabular}




\section{Serum antioxidant activity}

Nano-Se and SSe impacts on serum glutathione reductase (GR), total antioxidant capacity (TAC) and malondialdehyde (MDA) activities of growing rabbits are presented in Table (4). It is obviously clear that TAC and MDA activities differed $(\mathrm{P}<0.001)$ due to sex effect; female rabbits had higher TAC and GR activity than males, although the GR increase was insignificant; females were lower by $0.95 \mathrm{nmol} / \mathrm{mL}$ in MDA compared males $(\mathrm{P}<0.001)$. It is worth to mention that treatments supplemented significantly affected the status of the estimated antioxidants. Both of Nano-Se and SSe resulted in significant $(\mathrm{P}<0.001)$ increase of GR and TAC activity compared control, the upper hand was to Nano-Se with $2.96 \mathrm{U} / \mathrm{mL}$ and $0.091 \mathrm{mM} / \mathrm{L}$ increment over than control, respectively. MDA activity recorded a similar trend, but with significant $(\mathrm{P}<0.001)$ decrease than control. There were no significant differences obtained due to sex and treatment interactions effect.

\section{Serum lipids profile}

The effects of Nano-Se and SSe on the serum lipids profile of growing rabbit are listed in Table (5). Growing male rabbits varied significantly $(\mathrm{P}<0.001)$ in the lipids profile compared to females, except HDL concentrations. In general, male rabbits had higher mean values of triglycerides, HDL, LDL and VLDL compared to females, except TC and phospholipids. As regards treatments effect, each of TC, LDL, VLDL, triglycerides and phospholipids concentration decreased $(\mathrm{P}<0.001)$ due to Nano-Se administration compared to control. While, SSe showed the same trend for TC, LDL, and phospholipids without a significant difference from Nano-Se. On the other hand, Nano-se group had HDL $(87.46 \mathrm{mg} / \mathrm{dl}$; $\mathrm{P}<0.001)$ higher than the control and SSe; however Sodium selenite group showed highly significant $(\mathrm{P}<0.001)$ in triglycerides and VLDL than the other groups. Within each sex, the male rabbit's data revealed that Nano-Se and SSe showed low significant TC and phospholipids concentrations compared to the control, while this decrease was not significant in females. In case of VLDL and triglycerides, male rabbits showed a marked decrease (15.73 and $78.64 \mathrm{mg} / \mathrm{dl}$, respectively; $\mathrm{P}<0.001)$ due to Nano$\mathrm{Se}$ as compared with other groups. However, in females, SSe increased $(\mathrm{P}<0.001)$ VLDL and triglycerides by 3.53 and $17.69 \mathrm{mg} / \mathrm{dl}$, respectively compared to the control Table (5).

\section{Serum T3 and T4 levels}

There are comparable increases in T3 and T4 serum levels due to Nano-Se administration compared to the control, with the mean value of 3.551 and $87.569 \mathrm{nmol} / \mathrm{L}$, respectively $(\mathrm{P}<0.05)$. A similar trend was obtained in SSe group for only T3 as compared to the control (Figure 1). It is worth to mention that Nano-Se was more effective in increasing thyroid hormone than SSe.

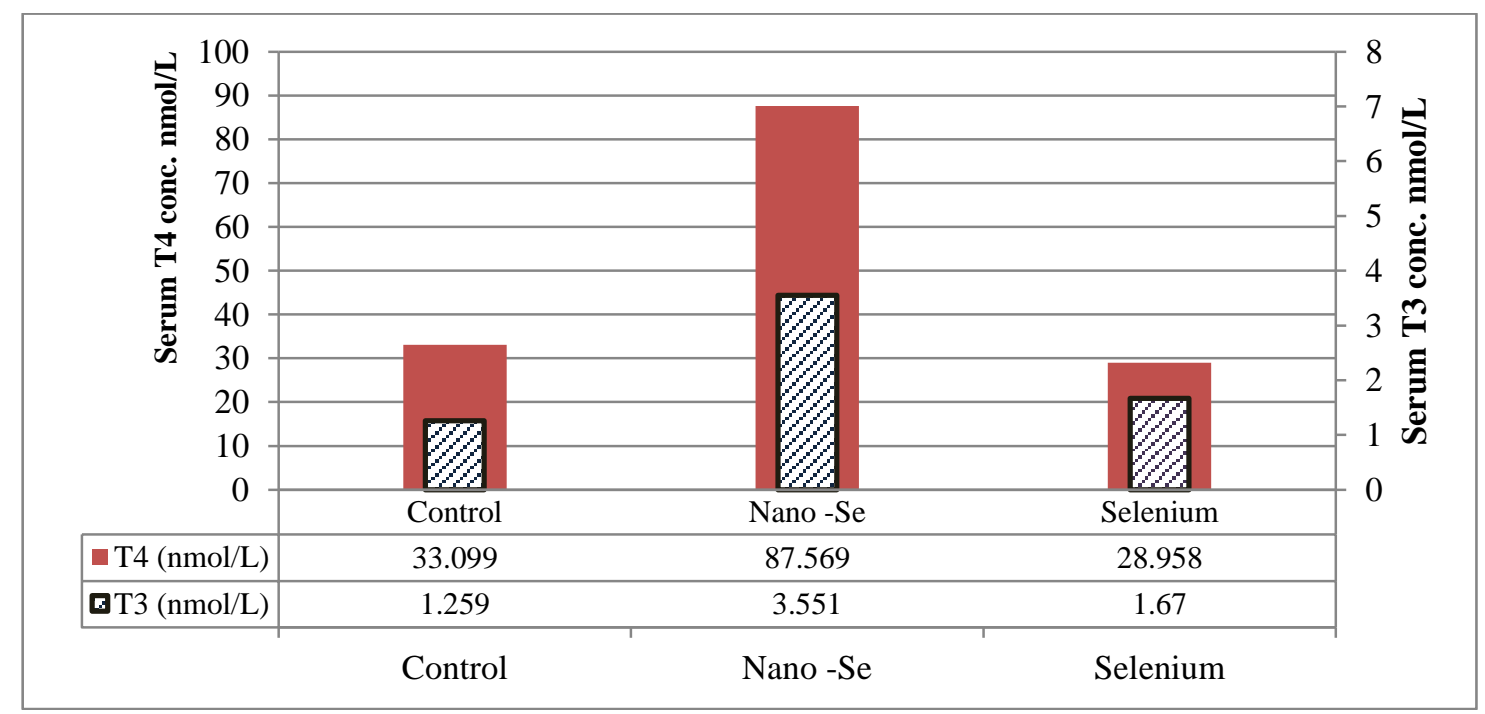

Figure (1): Effect of Nano-Se and sodium selenite on serum $T_{3}$ and $T_{4}$ levels of growing NWZ rabbits 


\section{Discussion}

In the present study, the results indicated positive effects of using nano-selenium supplementation on blood biochemistry in rabbits that lead to enhanced growth performance of growing NZW rabbits more than those of sodium selenite that are similar to previous results of Ebeid et al. [14] who found that Nano-Se supplementation led to the improvement on growth performance of growing rabbits by increasing the final body weight and daily gain in the growing rabbits. Moreover, Supplementation of Nano-Se $0.1 \mathrm{mg} / \mathrm{kg}$ diet to growing rabbits showed a significant increase in body weight gain at the period from 10-11 weeks of age, and were better in FCR (3.61) than the control (5.15; $\mathrm{P}<0.05)$, [11]. In goat bucks, the final Body weight and daily gain was increased $(P<0.05)$ nano-Se-supplemented group compared to the $\mathrm{SSe}$ and the control [34]. Dietary supplementation with Nano-Se or SSe for 20 weeks for layer grower birds significantly $(\mathrm{P}<0.05)$ improved final body weight compared with the control, the highest final body weight was in Nano-Se group $(0.15$ or $0.30 \mathrm{mg} / \mathrm{kg}$ diet). The best FCR was recorded by Nano-Se $(0.15 \mathrm{mg} / \mathrm{kg}$ diet $)$ in comparison with other groups. In this respect, the current results of Nano-Se and SSe for growth performance and FCR go in harmony with those of Mohapatra et al. [22]. Nano-Se particles possess equal efficacy as antioxidant similar to other selenium forms [38]. Such antioxidants can protect intestinal mucosa against oxidative damage and pathogens and limits peristaltic activity on digestive disorders preventing diarrhea, in addition to its immune modulating properties $[18,35]$. The improved feed/gain ratio (FCR) of animals feed Nano-Se could be related to the increased concentrations of the active form thyroid hormone in the serum of these animals $[36,16,24]$.

In the same trend of SSe current results, Amer et al. [1] reported that supplementation of growing rabbits with sodium selenite did not have any improving effect on BW, BWG and FCR; also, other investigators $[10,21]$ reported no effect for Se supplementation on body weight in rabbits.

The present results of liver enzymes activities, which recorded an increase in AST activity and a decrease in ALT activity due to Nano-Se supplementation, go in harmony with those of Mohapatra et al. [22] who suggested that serum
AST level was increased linearly and quadratically $(\mathrm{P}<0.05)$ with an increase in the concentration of Nano-Se in diet. On the contrary, another study [26] reported that Nano-Se and SSe supplementation increases ALT level as compared to the control; whereas, Nano-Se decreased AST more than SSe and control groups.

It is worth to mention that Nano-Se supplement group resulted in a significant increase of GR and TAC activities compared to SSe group, and the same trend with decreasing in MDA activity is shown in Table (4). These results are in agreement with those found by Radwan et al. [27] who suggested that Nano-Se administration caused a significant increase in GR activity and TAC as compared to the control and selenium groups. Since GSH is an indicator of oxidative stress, this demonstrates the advantages of Nano-Se over other forms of the element. Qin et al. [26] reported that Nano-Se and SSe groups showed TAC higher $(\mathrm{P}<0.01)$ than the control in rabbits. However, MDA contents significantly decreased in the treated groups than the control, and MDA of Nano-Se groups was lower than SSe $(\mathrm{P}<0.05)$. These results are in harmony with the present results, which stated that Nano-Se administration improved both GR and TAC activities and decreased MDA as compared to the control $(\mathrm{P}<0.001)$. Additionally, there were higher GR and TAC activities, and lower MDA in the rabbits that received Nano-Se than those of SSe (Table 4), this may be attributed to the fact that Nano-Se could enhance antioxidant activity in growing rabbits with a higher effect than SSe.

In the present study, each of total cholesterol, phospholipids, triglycerides, LDL and VLDL concentration decreased due to Nano-Se administration compared to SSe. On the contrary, HDL concentration was significantly higher in Nano-Se group than in SSe group Table (5).These results agreed with those of Amer et al. [1] who revealed significant decreases in TC and LDL in SSe group as compared to the control, attributing this effect to the decreased digestion coefficient (DC) of fat, since the DC of EE was significantly low in SSe-supplemented group. Also, Dehkordi et al. [7] reported that total cholesterol, triglycerides, and LDL contents were affected by SSe causing a significant reduction of them; meanwhile,receiving Nano-Se had a relatively greater effect than that of SSe. 
COMPARATIVE EFFECTS OF NANO-SELENIUM....

\begin{tabular}{|c|c|c|c|}
\hline Items & $\begin{array}{c}\text { GR } \\
(\mathrm{U} / \mathrm{mL})\end{array}$ & $\begin{array}{c}\text { TAC } \\
(\mathrm{mM} / \mathrm{L})\end{array}$ & $\begin{array}{c}\text { MDA } \\
(\mathrm{nmol} / \mathrm{mL})\end{array}$ \\
\hline \multicolumn{4}{|l|}{ Sex } \\
\hline Male & $30.72 \pm 0.40$ & $0.144 \pm 0.01$ & $12.75 \pm 0.40$ \\
\hline Female & $31.28 \pm 0.50$ & $0.170 \pm 0.01$ & $11.80 \pm 0.29$ \\
\hline Significance & N.S & $* * *$ & $* * *$ \\
\hline \multicolumn{4}{|l|}{ Treatment } \\
\hline Control & $29.11^{\mathrm{B}} \pm 0.79$ & $0.106^{\mathrm{C}} \pm 0.01$ & $14.61^{\mathrm{A}} \pm 0.43$ \\
\hline Nano-Se & $32.07^{\mathrm{A}} \pm 0.38$ & $0.197^{\mathrm{A}} \pm 0.01$ & $10.64^{\mathrm{C}} \pm 0.30$ \\
\hline $\mathrm{SSe}$ & $31.81^{\mathrm{A}} \pm 0.19$ & $0.167^{\mathrm{B}} \pm 0.01$ & $11.58^{\mathrm{B}} \pm 0.29$ \\
\hline Significance & $* * *$ & $* * *$ & $* * *$ \\
\hline \multicolumn{4}{|l|}{ Interactions $\mathrm{S} * \mathrm{~T}$} \\
\hline \multicolumn{4}{|l|}{ Male } \\
\hline Control & $28.92 \pm 0.68$ & $0.098 \pm 0.01$ & $15.50 \pm 0.50$ \\
\hline Nano-Se & $31.66 \pm 0.32$ & $0.182 \pm 0.01$ & $10.83 \pm 0.37$ \\
\hline $\mathrm{SSe}$ & $31.57 \pm 0.21$ & $0.151 \pm 0.01$ & $11.93 \pm 0.26$ \\
\hline \multicolumn{4}{|l|}{ Female } \\
\hline Control & $29.30 \pm 0.90$ & $0.113 \pm 0.01$ & $13.71 \pm 0.35$ \\
\hline Nano-Se & $32.49 \pm 0.43$ & $0.212 \pm 0.01$ & $10.45 \pm 0.23$ \\
\hline $\mathrm{SSe}$ & $32.07 \pm 0.16$ & $0.184 \pm 0.01$ & $11.24 \pm 0.31$ \\
\hline Significance & N.S & N.S & N.S \\
\hline
\end{tabular}

Table (5): Effect of Nano-Se and sodium selenite on serum lipids profile of growing NZW rabbits (means \pm SE)

\begin{tabular}{|c|c|c|c|c|c|c|}
\hline Items & $\begin{array}{c}\text { T. Cholesterol } \\
(\mathrm{mg} / \mathrm{dl})\end{array}$ & $\begin{array}{c}\text { Triglycerides } \\
\text { (mg /dl) }\end{array}$ & $\begin{array}{c}\text { phospholipids } \\
(\mathrm{mg} / \mathrm{dl})\end{array}$ & $\begin{array}{c}\text { HDL } \\
(\mathrm{mg} / \mathrm{dl})\end{array}$ & $\begin{array}{c}\text { LDL } \\
(\mathrm{mg} / \mathrm{dl})\end{array}$ & $\begin{array}{c}\text { VLDL } \\
(\mathrm{mg} / \mathrm{dl})\end{array}$ \\
\hline \multicolumn{7}{|l|}{ Sex } \\
\hline Male & $186.38 \pm 8.48$ & $109.64 \pm 2.44$ & $233.48 \pm 7.50$ & $65.49 \pm 2.17$ & $98.52 \pm 9.09$ & $21.93 \pm 0.49$ \\
\hline Female & $235.99 \pm 7.88$ & $91.98 \pm 2.11$ & $278.04 \pm 7.02$ & $64.44 \pm 2.17$ & $152.96 \pm 7.96$ & $18.40 \pm 0.43$ \\
\hline Significance & $* * *$ & $* * *$ & $* * *$ & N.S & $* * *$ & $* * *$ \\
\hline \multicolumn{7}{|l|}{ Treatment } \\
\hline Control & $238.83^{\mathrm{A}} \pm 10.28$ & $105.89^{\mathrm{B}} \pm 2.30$ & $280.56^{\mathrm{A}} \pm 9.16$ & $51.85^{\mathrm{B}} \pm 1.70$ & $165.81^{\mathrm{A}} \pm 10.30$ & $21.18^{\mathrm{B}} \pm 0.46$ \\
\hline Nano-Se & $192.46^{\mathrm{B}} \pm 5.33$ & $81.82^{\mathrm{C}} \pm 2.77$ & $238.70^{\mathrm{B}} \pm 4.68$ & $87.46^{\mathrm{A}} \pm 2.40$ & $87.97^{\mathrm{C}} \pm 6.22$ & $16.37^{\mathrm{C}} \pm 0.56$ \\
\hline $\mathrm{SSe}$ & $202.27^{\mathrm{B}} \pm 8.93$ & $114.73^{\mathrm{A}} \pm 1.77$ & $248.02^{\mathrm{B}} \pm 7.95$ & $55.89^{\mathrm{B}} \pm 2.42$ & $123.44^{\mathrm{B}} \pm 9.08$ & $22.95^{\mathrm{A}} \pm 0.36$ \\
\hline Significance & $* * *$ & $* * *$ & $* * *$ & $* * *$ & $* * *$ & $* * *$ \\
\hline \multicolumn{7}{|c|}{ Interactions $\mathrm{S} * \mathrm{~T}$} \\
\hline \multicolumn{7}{|l|}{ Male } \\
\hline Control & $230.07^{\mathrm{a}} \pm 10.67$ & $125.15^{\mathrm{a}} \pm 1.96$ & $272.76^{\mathrm{a}} \pm 9.50$ & $54.84 \pm 1.84$ & $150.20 \pm 11.19$ & $25.03^{\mathrm{a}} \pm 0.39$ \\
\hline Nano-Se & $161.39^{\mathrm{b}} \pm 7.26$ & $78.64^{\mathrm{d}} \pm 2.96$ & $210.44^{\mathrm{b}} \pm 6.33$ & $86.74 \pm 2.44$ & $57.58 \pm 8.37$ & $15.73^{\mathrm{d}} \pm 0.59$ \\
\hline $\mathrm{SSe}$ & $167.68^{b} \pm 7.50$ & $125.13^{\mathrm{a}} \pm 2.41$ & $217.24^{\mathrm{b}} \pm 6.68$ & $54.88 \pm 2.22$ & $87.78 \pm 7.73$ & $25.03^{\mathrm{a}} \pm 0.48$ \\
\hline \multicolumn{7}{|l|}{ Female } \\
\hline Control & $247.60^{\mathrm{a}} \pm 9.89$ & $86.63^{c} \pm 2.64$ & $288.36^{\mathrm{a}} \pm 8.81$ & $48.85 \pm 1.55$ & $181.42 \pm 9.40$ & $17.33^{c} \pm 0.53$ \\
\hline Nano-Se & $223.53^{\mathrm{a}} \pm 3.40$ & $85.00^{\mathrm{cd}} \pm 2.57$ & $266.94^{\mathrm{a}} \pm 3.03$ & $88.18 \pm 2.35$ & $118.35 \pm 4.07$ & $17.00^{\mathrm{cd}} \pm 0.52$ \\
\hline $\mathrm{SSe}$ & $236.86^{\mathrm{a}} \pm 10.35$ & $104.32^{\mathrm{b}} \pm 1.13$ & $278.81^{\mathrm{a}} \pm 9.21$ & $56.90 \pm 2.61$ & $159.10 \pm 10.42$ & $20.86^{\mathrm{b}} \pm 0.23$ \\
\hline Significance & $* *$ & $* * *$ & $* *$ & N.S & N.S & $* * *$ \\
\hline
\end{tabular}

${ }^{l}$ In each factor means in the same column with different superscripts are significantly different

$$
2 *=\mathrm{P}<0.05, * *=\mathrm{P}<0.01, * * *=\mathrm{P}<0.001
$$


Liao et al. [20] noticed that total serum cholesterol, triglyceride decreased linearly $(\mathrm{P}<0.05)$ due to Nano-Se $(0.3 \mathrm{ppm})$ administration in layer chicks up to eight weeks post feeding compare to inorganic sodium selenite. Similar to the present results, Se supplementation (inorganic and nanoparticles) has been reported to increase lowdensity lipoprotein (LDL) receptor activity in rats by [8] and decrease the 3-OH-methyl-glutaryl CoA reductase expression by [8] which leading to decreased in plasma LDL and total cholesterol levels [40]. Radwan et al. [27] noticed that NanoSe significantly reduced total lipids, total cholesterol, and increased HDL to total cholesterol ratio in maternal hens.

The significant increase of T3 and T4 due to NanoSe supplementation as compared to the control (Figure 1) goes in harmony with the findings of other researchers [28] who revealed that gavages $0.3 \mathrm{mg} / \mathrm{Kg}$ bodyweight Nano-Se increased T3 and $\mathrm{T} 4$ concentrations in albino rats as compared to the control $(\mathrm{P}<0.05)$. Changguang et al. [5] found that serum T3 level of $0.3,0.5 \mathrm{mg} / \mathrm{kg}$ Nano-Se treated animals significantly increased by $23.08 \%$, $24.08 \%$, respectively, and was significantly higher than that of sodium selenite group. Serum T4 level insignificantly $(\mathrm{P}<0.05)$ decreased at the end of the trial as compared with the control group. This result is on the contrary with the current T4 of Nano-Se treatment, but it agrees with SSe results Figure (1). Iodothyronine deiodinases are selenoenzymes that catalyze the activation (D1, D2) and inactivation (D3) of thyroid hormones. Although many mechanisms regulate the synthesis of deiodinases(TSH, thyroid hormones, cyclic AMP), selenium content also directly affects their activity and therefore, indirectly affects T3 synthesis. Selenium distribution in tissues is variable and selenoprotein synthesis is priortorized based on other studies [21, 13].Subsequent studies demonstrated that the activity of Nano-Se in up regulating selenoenzymes is comparable to that of selenite, while exhibiting dramatically decreased acute toxicity and more bioactive[30, 39, 42], this may explain theelevated $\mathrm{T} 3$ and $\mathrm{T} 4$ levels in rabbits supplemented with Nano-selenium.

The different physiological effects of Nano-Se and sodium selenite were probably related to the different absorption process and metabolic pathways. It has been reported that nanoparticles show new characteristics of transport and uptake and exhibit higher absorption efficiencies [20]. It was suggested that the superior performance of nanoparticles may be attributed to their smaller particle size and larger surface area, increased mucosal permeability, improved intestinal absorption and tissue depositions. Moreover, selenium nanoparticles also show high biological activity and good absorptive ability due to the interaction between the nanoparticles and $-\mathrm{NH} 2$, $\mathrm{C}=\mathrm{O},-\mathrm{COO}$, and $-\mathrm{C}-\mathrm{N}-$ groups of proteins [41].

\section{Conclusion}

The present study showed that supplementation of Nano-selenium enhanced growth performance of growing NZW rabbits by its positive changes that affect the blood biochemical constituents in comparison with sodium selenite supplementation. Therefore, dietary Nano-selenium supplementation seems to be more suitable for growing rabbits to improve meat production.

\section{References}

1-Amer, S.A., Omar, A.E. and Abd El-Hack, M.E. (2018) Effects of selenium-and chromiumenriched diets on growth performance, lipid profile, and mineral concentration in different tissues of growing rabbits. BiologicalTrace Element Research,18.https://doi.org/10.1007/s12011-018-1356-4

2-AOAC.(2000) 'Official Methods of Analysis of AOAC International.'(Gaithersburg MA: USA)

3-Beck, P.A., Wistuba, T.J., Davis, M.E. and Gunter, S.A. (2005) Effect of feeding supplemental organic or inorganic selenium to cow-calf pairs on Selenium status and immune responses of weaned beef calves. The Professional Animal Scientist 21,114-120.

4-Beckett,G.J. and Arthur, J.R. (2005) Selenium and endocrine systems. Journal of Endocrinology184, 455-465.

5-Changguang, L., Jingui. Z. and Jinyu, L. (2013) Effects of different sources and supplemental dosages of selenium on growth performance, immunity and thyroid hormones. China Feed 21,007.

6-DalleZotte, A. and Szendrö, Z. (2011) The role of rabbit meat as functional food. Meat Science 88, 319-331.

7-Dehkordi, S.K., Mohebbi, A., Aslani, M.R., Dehkordi, A.J. and Shahabi, A. (2016) Comparison of the effect of selenium Nano 
particles and sodium selenite on the serum and hepatic lipid profiles of rats following experimental exposure to cadmium.In the proceedings of International Conference on Nanomedicine and Nanobiotechnology,Paris, France.

8-Dhingra, S. and Bansal, M.P.(2006a) Attenuation of LDL receptor gene expression by selenium deficiency during hypercholesterolemia. MolecularCell Biochemistry 282, 75-82.

9-Dhingra, S. and Bansal, M.P.(2006b) Modulation of hypercholesterolemia- induced alterations in apolipoprotein B and HMG-CoA reductase expression by selenium supplementation. Chemico-biological interactions 161, 49-56.

10-Dokoupilová, A., Marounek, M., Skřivanová, V. and Březina, P. (2007) Selenium content in tissues and meat quality in rabbits fed selenium yeast. Czech Journalof AnimalScience 52, 165-169.

11-Dorra, T.M., El-Moghazy, G.M., Abo ElMaaty, H. M. and Eid, R.H. (2014) Effect of dietary supplementation with nano-selenium or glutamine on growth performance and carcass characteristics of growing rabbits feed diets containing two crud protein levels. Journal of Animal and Poultry production, Mansoura University 5, 549-562.

12-Drutel A., Archambeaud F. and Caron P. (2013). Selenium and the thyroid gland: more good news for clinicians. Clin. Endocrinol. 78 155-164.

13-Duncan, D.B. (1955) Multiple range and multiple F tests. Biometrics 11, 1-42.

14-Ebeid, T., Zeweil, H., Basyony, M. and Badry, H. (2012) The impact of incorporation of organic selenium into meat on growth performance, anti-oxidative status, and immune response in growing rabbits. In Proceeding of the 10th World Rabbit Congress, Sharm ElSheikh, Egypt, pages. 861-864.

15-Ellefson, R.D. and Caraway W.T. (1976) Lipids and lipoproteins. In 'Fundamentals of Clinical Chemistry'. (Ed. NW Tietz) pp. 474542. (Philadelphia).

16-Huffnann, P.R. (2007) Mechanisms by which selenium influence immune responses. Archivum immunologiae et therapiaeexperimentalis55, 289-297.
17-Jia, X., Li N and Chen, J. (2005) A subchronic toxicity study of elemental Nano-Se in SpragueDawley rats. Life Science 76, 1989-2003.

18-Kermauner, A. and Laurenčič,A. (2008) Supplementation of rabbit diet with chestnut wood extract. Effect on invitro gas production from two sources of protein. In Proceedings of the $9^{\text {th }}$ World Rabbit Congress, Verona, Italy, pages 689-693.

19-Kohrle, J., Jakob, F., Contempre', B. and Dumont, J.E. (2005) Selenium, the thyroid, and the endocrine system. Endocrine Reviews, 26, 944-984.

20-Liao, C.D., Hung, W.L., Jan,K.C., Yeh, A.I., Ho, C.T. and Hwang, L.S. (2010) Nano/submicrosizedlignan glycosides from sesame meal exhibit higher transport and absorption efficiency in Caco-2 cell monolayer. Food chemistry 119,896-902.

21-Marounek,M., Dokoupilová, A., Volek,Z. andHoza, I. (2009) Quality of meat and selenium content in tissues of rabbits fed diets supplemented with sodium selenite, selenized yeast and selenized algae. World Rabbit Science 17, 207-212.

22-Mohapatra, P., Swain, R.K., Mishra, S.K., Behera, T., Swain, P., Mishra, S.S., Behura, N.C.,Sabat, S.C., Sethy, K.,.Dhama, K. and Jayasankar, P. (2014) Effects of dietary nanoselenium on tissue selenium deposition, antioxidant status and immune functions in layer chicks. International Journal of Pharmacology 10, 160-167.

23-NRC (1977) 'Nutrient requirements of rabbits.' National Research Council (Natl. Acad. Press, Washington, DC: USA)

24-Özkan, S., Malayoğlu, H.B., Yalcin, S., Karadaş, F., Koçtürk, S., Cabuk, M., Oktay, G., Özdemir, S., Özdemir, E. andErgül, M. (2007) Dietary vitamin E ( $\alpha$-tocopherol acetate) and selenium supplementation from different sources: Performance, ascites-related variables and antioxidant status in broilers reared at low and optimum temperatures. British poultry science 48, 580-593.

25-Pappas, A.C. andZoidis, E. (2012) The Role of Selenium in Chicken Physiology: new insights. In ' Chickens: Physiology, Diseases and Farming Practices'. (Eds. I Kapur, AMehra) pp. 5169.(Nova Science Publishers, New York: USA) 
26-Qin, F., Chen, F., Zhao, F., Jin, T. and Ma, J. (2016) Effects of Nano-selenium on Blood Biochemistry, Liver Antioxidant Activity and GPx-1 mRNA Expression in Rabbits. In ' Proceedings of the International Conference on Biomedical and Biological Engineering '.page.166-171. (Chaina)

27-Radwan, N., Eldin, T.S., EL-Zaiat, A. and Mostafa, M.A. (2015) Effect of dietary nanoSelenium supplementation on selenium content and oxidative stability in table eggs and productive performance of laying hens. International Journal of Poultry Science 14,161-176.

28-Rezaeian-Tabrizi, M. andSadeghi, A.A. (2017) Plasma antioxidant capacity, sexual and thyroid hormones levels, sperm quantity and quality parameters in stressed male rats received nano-particle of selenium. Asian Pacific Journal of Reproduction 6, 29-34.

29-Saber, A. and Khalid, S.H. (2015) Selenium nanoparticles increase the testicular antioxidant activity and spermatogenesis in male rats as compared to ordinary selenium. International Journal of Advanced Research 3, 792-802.

30-Sadeghian, S., Kojouri, G.A. andMohebbi, A. (2012) Nanoparticles of selenium as species with stronger physiological effects in sheep in comparison with sodium selenite. Biological Trace Element Research146, 302-308.

31-SAS. (2000) SAS User's Guide. Cary, NC: Statistical Analysis System Institute Inc.

32-SAS. (2003) Version 9.3.1, SAS Institute Inc., Cary, NC, USA.

33-Shi, L., Xun, W., Yue, W., Zhang, C., Ren,Y., Liu, Q., Wang, Q. and Shi,L. (2011a) Effect of elemental nano-selenium on feed digestibility, rumen fermentation, and purine derivatives in sheep. Animal Feed Science Technology 163, 136-142.

34-Shi, L., Xun, W., Yue, W., Zhang, C., Ren, Y., Shi, L., Wang, Q., Yang, R. and Lei, F. (2011b)
Effect of sodium selenite, Se-yeast and nanoelemental selenium on growth performance, $\mathrm{Se}$ concentration and antioxidant status in growing male goats. Small Ruminant Research 96, 4952.

35-Surai, P.F. (2002) Selenium in poultry nutrition 2. Reproduction, egg and meat quality and practical applications. World's Poultry Science Journal 58,431-450.

36-Surai, P.F.(2006) 'Selenium in nutrition and health( $\left(1^{\text {st }}\right.$ edn.)' (Nottingham Univ. Press, Nottingham: UK)

37-Tapiero, H., Townsend, D.M. andTew, K.D. 2003. The antioxidant role of selenium and seleno-compounds. Biomedicine \& pharmacotherapy57,134-144.

38-Wang, H., Zhang, J. and Yu, H. (2007) Elemental selenium at nano size possesses lower toxicity without compromising the fundamental effect on selenoenzymes: Comparison with selenomethionine in mice. Free Radical Biology and Medicine 42, 1524- 1533.

39-Wang, R.R., Pan, X.J. andPeng, Z.Q. (2009) Effects of heat exposure on muscle oxidation and protein functionalities of pectoralis majors in broilers. Poultry Science 88, 1078-1084.

40-Yang, K.C., Lee, L.T., Lee, Y.S., Huang, H.Y., Chen, C.Y. and Huang, K.C. (2010) Serum selenium concentration is associated with metabolic factors in the elderly: a crosssectional study. Nutrition \& metabolism7, 3844.

41-Zhang, J.S., Gao, X.Y., Zhang, L.D. andBao, Y.P. (2001) Biological effects of a nano red elemental selenium. Biofactors 15,27-38.

42-Zhang, J.S., Wang, X.F. andXu, T.W. (2008) Elemental selenium at nano size (Nano-Se) as a potential chemopreventive agent with reduced risk of selenium toxicity: Comparison with Semethylselenocysteine in mice. Toxicological sciences 101, 22-31. 